\title{
Grocery Retailing in the I4.0 Era*
}

\author{
Sergio Barile ${ }^{*}$ Francesco Polese ${ }^{* *}$, Debora Sarno ${ }^{* * *}$
}

\begin{abstract}
Grocery retailing is facing many challenges and digital transformation in the current market-driven space competition. Grocery retailing renews itself based on Industry 4.0 technologies (typically related to manufacturing) and network economies, under a value co-creation perspective. The major trends of technology adoption in grocery retailing are identified and compared them with the main categorizations of the Industry 4.0. Then, a framework to match network aggregation levels and Industry 4.0 technologies is proposed, to highlight the main technological drivers for future grocery retailing value co-creation. New networks, network economies, platforms and ecosystems derive, and new issues for management emerge.
\end{abstract}

Keywords: Grocery Retailing; Network Economies; V-Commerce; Service; Collaboration; Industry 4.0; Global Markets

\section{Grocery Retailing Transformation}

Nowadays, market globalization and continuous increase of mobility of people, goods, knowledge and ideas have brought companies to focus on market relationships (Brondoni \& Lambin, 2001). Indeed, since the competitive space has become enlarged and undefined, companies need more than ever to collaborate in global networks - even in terms of both equity and non-equity alliances - at least in order to keep informed about the market space to manage and in which competing (market space management and competition, Brondoni, 2002). This can be magnified by the concept of value co-creating networks, which involve customers and providers in the integration of resources for a benefit (Lusch \& Vargo, 2014).

Grocery retailing is facing a huge transformation and new challenges (among others, the online transition) and needs a renew also to avoid to be bought by generalist on-line retailers as Amazon (as happened to Whole Foods, Harrison, 2018) or search engines as Google (which has recently invested in Alibaba rival, Lee, 2018).

In parallel, Industry 4.0 technologies and paradigm are providing a solid base to shape the future smart factory (Indri, 2017).

\footnotetext{
*The Authors: Barile, S. § 1, 3.1; Polese, F. § 3, 6; Sarno, D. § 2, 4, 5

*Full Professor of Management, Sapienza University of Rome, (sergio.barile@uniroma1.it)

** Full Professor of Management, University of Salerno, (fpolese@ unisa.it)

*** Professor of Planning and Strategic Management, Sapienza University of Rome, (debora.sarno@uniroma1.it)

Edited by: University of Milano - Bicocca

ISSN: 1593-0319

Barile, S., Polese, F., Sarno, D. (2018). Grocery Retailing in the I4.0 Era. Symphonya. Emerging Issues in Management (symphonya.unimib.it), 2, 38-51.
}

http://dx.doi.org/10.4468/2018.2.4barile.polese.sarno 
Given these conditions, the following research question is investigated: can grocery retailing renew itself based on Industry 4.0 technologies and network economies in market-driven competition under a value co-creation perspective?

The rest of the paper is structured as follows: networks, network economies, value co-creation and market-driven competition are presented in Section 2; the history and challenges of grocery retailing are then described (Section 3); the main technologies and drivers of the Industry 4.0 are shown, highlighting that they are mainly related to manufacturing (Section 4); in Section 5 a new era for grocery retailing is disclosed by answering to the research question; implications and conclusions follow.

\section{Networks and Value Co-Creation, Network Economies and Market-Driven Management}

Since each actor cannot evolve in a vacuum because he/she must obtain resources from the local environment and other actors, networks are the way to integrate and exchange resources.

The marketing focus on networks emerged in 1990s due to the birth of relationship marketing in industrial and consumer markets, and the emphasis on cooperative more than adversarial relations (Wilkinson, 2001). The general definition of networks attributes to them a scale-free meaning (that is, there is no limit to their size) and a random occurrence. In marketing, networks are built and defined for a purpose, which requires control and gives rise to limited and planned networks. Partners, suppliers, shareholders, and other stakeholders offer access to external resources as an alternative to a company acquiring own resources. A member of a network based on cooperation cannot solely maximize its own benefit at all times but - within reasonable limits - has to show respect for the other members. Moreover, there is a cost for building, maintain or finding a network (Gummesson, 2008b). Thus, the network approaches to B2B marketing (Gummesson \& Polese, 2009) introduced the concept of many-to-many marketing (Gummesson, 2008a), initially inspired by the IMP researchers (Håkansson \& Snehota, 2000; Wilkinson, 2008), which "describes, analyses and utilizes the network properties of marketing" (Gummesson, 2008b).

Normann (2001) made the connection between networks of relationships and value co-creation, suggesting that a network configuration can increase resource density for customers. Further, according to the Service-Dominant Logic paradigm (Vargo \& Lusch, 2008), the distinction between consumers and producers became blurred, and the focus switched on actors' interactions and value co-creation (Akaka \& Chandler, 2011). Service is defined as the application of resources (mainly knowledge) for the benefit of another party, and every exchange of organizations, markets and individuals is due to service; service is exchanged for other service in networks (Vargo \& Lusch, 2008). Given these premises, networks were recognised as mediators of value co-creation, enabling multiple actors (both suppliers and consumers) to access, adapt and integrate resources in order to co-create value for themselves, and for others (Akaka et al., 2015; Polese et al., 2018).

A different perspective on networks purpose and value was provided by Shapiro \& Varian (1999), according to whom the value of connecting to a network depended on the number of other people already connected to it. These authors linked the concepts of networks to the information economy (economy based on the exchange of knowledge, information and services rather than physical goods and services). In particular, they maintained that the information economy was driven by networks and differed from old economies based on economies of scales, in which large sells 
lower the unit costs. Thus, they defined the main underlying principle of network economies: positive feedback of the network ("Positive feedback makes the strong grow stronger... and the weak grow weaker, leading to extreme outcomes" p.174, as winner-take-all market). Such feedback can be described in terms of: demand-side economies of scales (related to the convenience of customers to adopt the solutions provided by the network; the extreme case is a de facto industry standard), network externalities (proportional to the size of the network - the value of a network goes up to the square of the number of the users according to the Metcalfe's law), and collective switching costs (the combined switching cost of all users to be overcome in case of the introduction of new but incompatible technologies). The authors identified four generic strategies to introduce technological innovations in the marketplace by combining the following trade-offs (Shapiro \& Varian, 1999): (i) compatibility vs. performance, and (ii) control vs. openness. Thus, the strategies are: performance play, controlled migration, open migration and discontinuity.

As expected, network economies can be analysed from multiple perspectives, ranging from intellectual property rights (Rifkin, 2000), to digital and information infrastructures, which have clearly participated to enable the phenomenon. Recently, a different evolution of the concept of network has been provided in terms of networked economy: "It's an emerging type of economic environment arising from the digitization of fast-growing, multi-layered, highly interactive, real-time connections among people, devices, and businesses" (MIT Technology Review Insights, 2014). SAP identified three main areas in which it will have the most impact: earning customer loyalty, enabling open innovation, and enhancing resource optimization. Finally, a structural perspective on networks was developed by Achrol \& Kotler (1999), who analysed the network phenomenon identifying several aggregation levels: internal (enabling the reduction of hierarchy and opening companies to their environment), vertical (promoting partnership between sequentially dependent functions and independent skill-specialized companies), intermarket (focusing on horizontal synergies across industries) and opportunity networks (built around customer needs and market opportunities).

The new market boundaries and the need to share resources in the global networks depend on the conditions of the market space. In particular, there are three possible market-driven conditions (Brondoni \& Lambin, 2001): demand exceeding supply, equilibrium between offer and demand, and over-supply, a situation in which there is a surplus of offers and an abundant availability of variety due to a production significantly higher than the potential absorption of demand. This condition clearly emphasizes the importance of immaterial resources and continuous innovation. Thus, the strategic leverage shifts from goods to knowledge, and the main assets become the corporate intangible ones, such as company culture, information system (which allows companies to collaborate) and brand equity (Brondoni, 2000-2001). The challenges of the global business economy can be managed by means of "structured, widespread and high interconnected" networks (Brondoni, 2018).

This stands for distribution too. The globalization of the distribution, indeed, has generated the strengthening of the role of distributors and commercial intermediaries, which have become sometimes also competitors by developing their own brands (competitive trade, Brondoni, 2002). Other variables to take into account in the case of excess of offer are pull trade and consumer policy, final selling price, and variable direct cost of transaction. They can be implemented by adopting "shelf policies" (proximity to the space and time of the customer choice), which can be physical or virtual (virtual windows), and are developed to satisfy instable "bubbles of demand" 
(instable aggregation of customers based on contingent needs, contraposed to market stable segments, Brondoni, 2000-2001).

Thus, the emerging market-based organization in the network economy, particularly in presence of over-supply, has to be oriented to a positive competition, keeping continuously informed and close (shelf policies) to the needs of the market bubbles and being flexible to timely identify and satisfy them, while being networked and ready to change (time-based competition).

In the following section, grocery retailing history is presented, and it is shown how it is increasingly becoming a globalised and over-supplied market. These new trends in grocery retailing ask for a rethink of the market-driven competition that should be more and more based on network economies oriented to value co-creation. Indeed, they can enable collaborative initiatives to conceptualize, develop and introduce and new shared technology solutions and digital platforms (de Reuver, 2017) to survive in the market.

\section{Grocery Retailing, History and Challenges}

The history of grocery retailing is constellated of challenges and changes.

According to Stanton (2018), until mid-1800s, food retailing consisted of small dry grocers' corner stores spread throughout urban areas. They were independent and unaffiliated and have a little bargaining power with respect to their wholesalers or other suppliers.

At the beginning of the twentieth century, they became to aggregate forming chains. Then, standardized aisles and product offering came, later logistic system of warehouses raised, finally they created private labels and store brands (Stanton, 2018).

A huge change was self-service concept, introduced in USA in the early 1990s and established in 1930, to allow customers to "walk the stores" and potentially increase the impulse shopping. This implied a revolution in the food processing, and the birth of branding. A shared definition of supermarket comprehended at this stage three conditions (Tilley \& Hicks, 1970): (1) the sales area must be at least 2000 square feet; (2) there must be a complete range of foodstuffs and a basic range of household goods on sale; (3) self-service system in operation with at least three checkouts. A research on a wide set of supermarkets showed that the average transaction value for supermarkets increased with the size of supermarkets, while the smaller supermarkets were the most profitable when the stockholding, administration and transport expenses were neglected (Tilley \& Hicks, 1970). Similarly, a study from Arndt \& Olsen (1975) demonstrated that the economies of scales seemed to disappear when the retailing stores were big enough to be considered as supermarkets.

In the 1950s, the supermarkets lived the contentment era, and the "slotting allowance" was introduced to charge manufacturers of the slots of shelves (Stanton, 2018). This increased also the price of the goods. In the non-traditional supermarket era new food retailers changed this paradigm avoiding the fees (allowing high savings) and introducing goods other than food (hypermarkets such as Walmart and Carrefour). Private labels and secondary brands started to be sold by hard discounter (as Aldi or Lidl). Then, the consolidation phase came, and many successful independent chains (probably more responsible to local customers) were acquired by bigger companies in order to increase sales revenues (supply chain expansion, not networks). The non-food store era followed, in which they started selling other dry 
groceries and moved back to urban areas, opening long hours and becoming proximity (Bordoli, 2015) and convenience stores.

\subsection{Grocery Retailing Today}

Nowadays, one of the major challenge of food retailing is the emphasis on prepared foods to avoid workers to go to supermarkets and cook from scratch. Clearly, main competitors are restaurants (McGrath, 2016). Another trend can be identified in targeting, since targeting consumers and opening stores for specific targets (healthy food, or exotic food, or fresh produce selection) or social movements (Sebastiani et al., 2013) has become very common (Yousept \& Li, 2004).

With respect to the customer experience, recent studies advocated omnichannel retailing, defined as a consistent, integrated shopping experience across all channels maintained by the retailer in order to provide a seamless and synchronized customer experience (Levy et al., 2018). Among channels, brick-and-mortar proposed virtual supermarkets, which are physical stores in which virtual technologies are implemented, as smart digital signage advertising, touchscreens, mobile and social promotions, fames, 3D or augumented reality for immersive experience (Demirkan $\&$ Spohrer, 2014). However, one of the biggest challenges is online. Many studies coped with the definition of the best characteristics to candidate goods or services to the internet selling or, to the contrary, of the main characteristics to exclude products from e-commerce initiatives. In some studies (Liebowits, 2002), grocery items were defined not attractive mainly because of logistic issues (problems of delivery time or temperature and high transportation cost if compared to final price) or being experience products (like fruits and meat, that the customer want to see before buying). However, already some decades ago, several initiatives tried to make online grocery shopping a viable market. The major players were HomeGrocer, Peapod (using existent distribution centers and systems), and Webvan (with automated warehouses and the development of special trucks). Lately, online supermarkets started to gain popularity (Riboldazzi, 2015) and some brick-and-mortar incumbents entered the online grocery market, as the UK's Tesco (Yousept \& Li, 2004). Thus, among the emerging models of online supermarket adoption, there are identified (Yousept \& Li, 2004): virtual pure plays (non-supermarket with an online-only offering, which can have partnership with existent brick-and-mortar providers or not); baby e-supermarkets (subsidiaries of existing supermarkets), and hybrid models.

Online supermarkets have become to be praised for channel development and coordination, business scope redefinition, development of fulfilment centre model and core processes, new ways of customer value creation, and online partnerships (Yousept \& Li, 2004). Already in 2014, more than $46 \%$ of European shoppers bought products on line and European online B2C sales grew by 14\%, culminating at around $€ 424$ billion (EcommerceEurope, 2015). It is expected that, despite the diffidence of many, online supermarkets will gain - together with smaller stores - around $50 \%$ of the sales of supermarkets and hypermarkets by 2025 (Bain\&Co, 2016). Clearly, among the strategies suggested by Bain\&Co (2016), there is the engagement in a holistic digital transformation.

Nowadays, the empowerment of customers has increased significantly due to mobile phones and smart devices that allow them to buy everything everywhere (Grewal et al., 2018). 
Moreover, big data and analytics are playing an important role to understand customers, product prices and services dynamically (Brandlow et al., 2017). Indeed, since there are increasing investments in online advertising, and customers comment their purchasing on line, even when sells are not carried out there, contemporary retailers can gain greater insights into their customers by combining data related to purchasing and location with social media data, so they are investing huge capitals on it (Grewal et al., 2018). This has been assumed to increase the profitability acting at four levels: market, firm, store and customer (Kumar et al., 2017). In physical store, for example, this can be translated in geo-fenced module ads. Sentiment analyses of comments are another opportunity.

However, the shift in consumption patterns of customers is not only due to the change of the offers based on analytics, but also to the new capabilities provided by Internet of Things (IoT), Artificial Intelligence (AI), blockchain technologies, and robotics. Indeed, Grewal et al. (2018) reported the raise of other new technologies in retailing market:

- AI to provide, for example, product recommendations and physical location of products. Given that customers often prefer to search on smartphones rather than interact with salespersons (preferring self-service systems, Demirkan and Spohrer, 2014), Macy's launched a mobile application to navigate its stores named On Call, which uses IBM's Watson and smartphone location services (Arthur, 2016a). Another adoption of Watson was launched by The North Face to develop a Fluid Expert Personal Shopper (Arthur, 2016b);

- Frontline service robots, not only for delivering (using drones or driverless vehicles). Indeed, McDonald announced to install service robots globally in order to eliminate the need for cashiers (Kim, 2017);

- IoT, for inventory optimization and distribution centre efficiency, also combined with blockchain technology, to increase the reliability of the data along with the supply chain, determining also disintermediation and lower transaction costs (Nowiński \& Kozma, 2017). The recent solution proposed by Amazon Go of cashier-less grocery stores (paying with smartphone apps and virtual checkouts seem not to be the future of retail for several reason (Harrison et al., 2018).

Moreover, other emerging technologies are Virtual Reality (VR, which is completely immersive and utilises wearable devices blocking out the real world both in stores than at home) and Augmented Reality (AR, which combines real and computer generated digital information in the view of the user). In this regard, Bonetti et al. (2017) developed a comparative timeline analysis of AR and VR in retail. It is evident that the main downside of VR is the hardware requirements which makes it not easily scalable. Notwithstanding, some studies reported that V-commerce (virtual commerce in Second Life style), with physical presence, can play a role in positively influencing costumers' brand-self connection as well as their evaluation of spokesavatar credibility (Jin and Bolebruch, 2009). Indeed, according to Forbes the future of retail is in AI and VR (Arthur, 2016b) mainly because new generations are particularly expectant of the new experiential nature of stores and want to be entertained also by VR and AR technologies (80\%) (Arthur, 2016b). Coherently, Nielsen (2017) found that $68 \%$ of buyers is interested in making online purchases using VR and that current gamers are the most attracted. Several applications are being developed, such as the one of eBay in partnership with Myer or that of Alibaba with Macy's department store. In the specific context of the supermarkets in Italy, it has been developed SelfZone (Diana, 2016), created for market analysis purposes but ready for v-commerce. McKone et al. (2016), estimating that investments in AV/AR 
in retail world will be around 30 billion of dollars in 2020, suggest not to wait for the killer application but set off on this new path to renew competitiveness.

Grocery retailing is an over-supply market and is facing a deep transformation. Many new comers are introducing in the market, and the competition seems to be based on technologies, given that consumer behaviour can nowadays be investigated in detail. The list of technologies involved in modern grocery retailing seem to be similar to the one adopted in Industry 4.0 scenario. In the following section, this industrial revolution is briefly reviewed, looking for other opportunities and threats to design new networked market-driven grocery retailers.

\section{Industry 4.0 in Manufacturing and Services}

Industry 4.0 (I4.0) refers to a politically established target for the production industry to come. It was firstly supported by the German government and is of great importance in Europe and the whole world (it has been listed as a main topic on the 2016 World Economic Forum's agenda) to remain competitive in the future despite globalization (Rennung et al., 2016) while shortening product lifecycle and increasing customizations (Weyer et al., 2015). It is also known as the forth industrial revolution since it is considered to come after the first (steam machine that opened the industry age), second (application of electricity to industry), and the third one (data processing for computer integrated manufacturing). Some authors maintained that it intends to create "an omnipotent cyber system, integrating different sociotechno-economic functions to allow fully automated production, integrated with the Internet of Things" (Rüttimann \& Stöckli, 2016, 486) to allow apps and internetbased production scheduling matching provisioning and demand with the highest flexibility. Multiple opportunities and benefits seem to derive from it, ranging from highly flexible mass production, real-time coordination and optimisation of value chains, reduction of complexity costs or the emergence of entirely new services and business models (Hofmann \& Rüsch, 2017).

One of I4.0 main challenge is to integrate IoT into the manufacturing systems in order to shape Cyber Physical Systems (CPS), which are transformative technologies for managing interconnected systems between their physical assets and computational capabilities (Baheti \& Gill, 2011) in a way that cannot be achieved by traditional automation (Weyer et al., 2015). Given the growing use of sensors and networked machines (IoT), the huge amount of generated data can be also used to leverage the interconnettivity for intelligent, resilient and self-adaptable machines (National Institute of Standards and Technology, 2013). Thus, by means of CPS, information can be closely monitored and synchronized between the physical factory floor and the cyber computational space in a smart manner (Lee et al., 2015). A literature review showed that there are many different research streams related to I4.0 (Brettel et al., 2014).

Under the I4.0 paradigm, companies can overcome the current rigid planning and production processes and start collaborating under a virtual process chain and production networks. Indeed, product traceability (achievable by means, for example of RFID) and information sharing become increasingly affordable since real-time information and control can be distributed to the shop-floor level. This is particularly interesting in case of simultaneous development of product families and their related supply-chains (Khalaf et al., 2011) and manufacturing capabilities (Brettel et al., 2014). 
Many classifications of the drivers of I4.0 have been provided in literature. For example, Hofmann \& Rüsch (2017) indicated CPS, IoT, Internet of Services (related to services made available thanks to web technologies), and Smart factory. In particular, Smart factory results to be enabled by CPS communicating over IoT and IoS. It is a decentralised production system in which "human beings, machines and resources communicate with each other as naturally as in a social network" (Kagermann et al., 2013, p. 19).

According to other studies, the five main features of I4.0 are (Lu, 2017): digitization, optimization, and customization of production; automation and adaptation; human machine interaction; value-added services and businesses, and automatic data exchange and communication.

Another study grouped the key technologies and concepts related to I4.0 in three clusters (Oesterreich \& Teuteberg, 2016):

- smart factory (in which CPS, IoT and Io Services, additive manufacturing, human computer interaction, etc.)

- simulation and modelling (simulation tools, AR/VR, mixed reality (MR), etc.)

- digitalisation and virtualisation (cloud computing, big data, social media, etc.)

In particular, AR, VR and MR seemed to be at the formative stage, with applications on construction sites or Smart Glasses offered for enabling instruction manuals or remote support in hands-free mode (Oesterreich \& Teuteberg, 2016).

Although concepts and studies focus on production of goods, the I4.0 framework could be implemented in the services environment too (Rennung et al., 2016). For example, a study investigated how business models of companies can be affected by I4.0 and clusterized the experiences coming from different industries including food processing, information technology, and medicals (Voigt \& Kiel, 2015). According to Rennung et al. (2016), service engineering and management can be an important component of I4.0 mainly in the service evaluation phase. On the other hand, manufacturing servitization in I4.0 has been proposed (Lee et al., 2014), since it changes manufacturers' value propositions by innovating organization's capabilities and processes to shift from selling products, to selling an integrated product and service offering (Martinez et al., 2010).

\section{A New Era for Grocery Retailing}

All the aforementioned considerations bring to the hypothesis that, since grocery retailing is moving on-line and is coping with high competition, according to marketdriven management, new global networks, mainly based on the sharing of intangible resources (as technological solutions or new digital platforms), should be put in place to adopt shelf-policies, capture demand bubbles, and co-create value.

I4.0 technologies, even not exploited a lot till now in the services sector, should be embraced to facilitate the networking. In particular, using the previously presented classifications provided by Oesterreich \& Teuteberg (2016) for the key technologies and concepts of I4.0, and by Achrol \& Kotler (1999) for the different aggregation levels of the network phenomenon, the following networks and I4.0 concepts may be integrated:

- a wider foreword vertical network with customers mainly based on simulation and modelling (internal and vertical partnerships). Indeed, since retailers are the interface between consumers and producers, they should exploit simulation and modelling opportunities based on AR/VR/MR to engage customers both providing new services and experiences like intelligent shop assistants, or sharing 
comments and advices with their social networks and communities. These services should be provided on-line or in store according to an omni-channel retailing strategy with shelf-policies. Gaming should be investigated as an enabler of customers' engagement with the grocery retailer. Positive feedback from the network in terms of participation to the initiatives of the retailers should be perceived by clients mainly in terms of demand-side economies of scales. Indeed, solutions should seem convenient to the customers because they can find all they need, or they can share their experiences with other users belonging to the same social network. In turn, in a service-for-service exchange logic, the knowledge that retailers can acquire on their customers due to big data analytics could be used to further adapt their value propositions to the needs and perceptions of the customers (Eggert et al., 2018);

- a deeper backword vertical network with suppliers mainly based on smart factory (internal and vertical partnerships). As already stated, customers' data should be employed internally to redesign value propositions, and directly and timely reported to suppliers to adjust wholesalers' products portfolio, manufacturers production, investments for new products, and production of raw materials under a collaborative logic (Tassinari, 2015). Thus, all technologies of smart factory could be fully exploited, from CPS to IoT;

- horizontal network among different grocery retailers mainly based on digitalization and virtualization (intermarket). Indeed, to make all these initiatives really affordable and effective, also given the high competition and the changing bubbles of demand, the platforms and technical solutions adopted to engage consumers should be enough reliable, smart, spread and well-furnished to sustain not-occasional services encounters. The convenience researched by customers requires that retailers work in networks to develop, maintain, communicate and improve new common solutions, and eventually obtain economies of scales in purchasing, distribution and marketing. This implies on one hand to share investments on digital ecosystems, for example giving the birth to v-commerce, on the other to create the conditions for the emergence of a service ecosystem of multiple actors (both suppliers and customers) to co-create value (Vargo \& Lusch, 2016).

Virtual pure plays may be jointly developed and integrated with CPS to allow a group of companies to compete in the market space with innovative and up to date technologies. These platforms may be opened to other brands, intelligent shop assistants and different social networks to really engage users while building network economies by means of software open artefacts. The adoption of virtual platforms would reduce inventory holding costs, also centralizing warehouses. Moreover, economies of scales in purchasing would be achieved.

Every I4.0 artefact (both in manufacturing and in services sector) developed according to these premises should be practically developed according to a service perspective to simplify service exchange and, thus, value co-creation.

These considerations bring to the affirmative answer to the research question posed in section 1.

\section{Emerging Issues and Conclusions}

According to the considerations provided in the previous sections, grocery retailing can really renew itself based on Industry 4.0 technologies and network economies in market-driven competition. This assertion has multiple emerging implications for 
researchers and managers, mainly inspired by Service Dominant logic (Vargo \& Lusch, 2016) and Viable Systems Approach (Barile et al., 2016; Polese et al., 2017) thinking.

From a technical point of view, new solutions should be scalable or at least modular in the way that other can exploit the potential of current technology while further improving it. This will give positive feedback to the participating networks in the network economies perspective. Indeed, the future competition in retailing could be based on the establishment of industry standards for VR/AR and AI technologies.

Another emerging issue is integrating predictive and prescriptive findings of big data analytics backward to food processors and producers to effectively introduce changes in organizational and operations processes (Martinez et al., 2017). New online platforms could involve multiple brands and multiple products (food, clothing, etc.) temporary aggregated for specific bubbles of demand.

From a theoretical point of view, researches should focus on new retailing network business models, able to provide customers the best engaging experience while keeping prices low. This will also mean that new partnerships with other retailers and suppliers should be defined to avoid to go back to the slotting allowance of the 1950'.

From a managerial point of view, a great effort should be put on selecting the best partners to give birth or sustain current networks oriented to the future era of grocery retailing. Intentionality sharing and consonance should be some structural variables to successfully co-create value in collaborative viable networks. Flexibility and loosely coupling are needed to adapt and change in new retailing market-driven, but relationships with actors retaining critical and viable resources will be of significant support to share data and risks.

Careful attention should be given to service design, in order to incorporate shared institutional arrangements in new technological solutions and enable every actor of the network to perceive clear value propositions and evident benefit in the servicefor-service exchange (Vargo et al., 2015). Indeed, market innovations in retailing should effectively integrate the classical three dimensions (e.g. product, process, and organisation) while leveraging on onmichannel retailing strategies to be introduced to the customers and become market practices.

\section{Bibliography}

Achrol, R. S., \& Kotler, P. (1999). Marketing in the Network Economy. Journal of Marketing, 63(SUPPL.), 146-163.

https://doi.org/10.2307/1252108

Akaka, M. A., Vargo, S. L., \& Lusch, R. F. (2015). An Exploration of Networks in Value Cocreation: A Service-Ecosystems View. Review of Marketing Research, 9 Special Issue - Towards a Better Understanding of the Role of Value in Markets and Marketing, 15-50.

Akaka, M. A, \& Chandler, J. D. (2011). Roles as Resources: A Social Roles Perspective of Change in Value Networks. Marketing Theory, 11(3), 243-260.

https://doi.org/10.1177/1470593111408172

Arndt, J., \& Olsen, L. (1975). A Research Note on Economies of Scale in Retailing. The Swedish Journal of Economics, 77(2), 207-221. https://doi.org/10.2307/3438917

Arthur, R. (2016a, July 20). Macy's Teams with IBM Watson for AI-Powered Mobile Shopping Assistant. Forbes. Retrieved from

https://www.forbes.com/sites/rachelarthur/2016/07/20/macys-teams-with-ibm-watson-for-aipowered-mobile-shopping-assistant/\#4aad3b8b7f41 
Arthur, R. (2016b, June 15) Future of Retail: Artificial Intelligence and Virtual Reality Have Big Roles to Play. Forbes. Retrieved from

https://www.forbes.com/sites/rachelarthur/2016/06/15/future-of-retail-artificial-intelligence-andvirtual-reality-have-big-roles-to-play/\#6dcf9447f9df

Baheti, R, \& Gill, H. (2011). Cyber-Physical Systems. The Impact Control Technology, 1-6.

Bain \& Company (2016, April 13). The Incredible Shrinking Retail Channel: Market Share for Europe's Traditional Hypermarkets, Supermarkets Could Plummet to Less Than 50 Percent by 2025 as Consumers Flock to Value and Smaller Stores and Online. Retrieved from http://www.bain.com/about/press/press-releases/Retail-Shifts-in-CPG-Press-Release.aspx

Barile, S., Lusch, R., Reynoso, J., Saviano, M., \& Spohrer, J. (2016). Systems, Networks, and Ecosystems in Service Research. Journal of Service Management, 27(4), 652-674. https://doi.org/10.1108/JOSM-09-2015-0268

Bonetti, F., Warnaby, G., \& Quinn, L. (2018). Augmented Reality and Virtual Reality in Physical and Online Retailing: A Review, Synthesis and Research Agenda. In: T. Jung \& T. M. Dieck (Eds.) Augmented Reality and Virtual Reality. Progress in IS (pp. 119-132). Springer, Cham.

Bordoli, M. (2015). Proximity Approach as an Option in Global Markets. Symphonya. Emerging Issues in Management (symphonya.unimib.it), (5), 36-40.

http://dx.doi.org/10.4468/2015.5.04bordoli

Bradlow, E. T., Gangwar, M., Kopalle, P., \& Voleti, S. (2017). The Role of Big Data and Predictive Analytics in Retailing. Journal of Retailing, 93(1), 79-95.

https://doi.org/10.1016/j.jretai.2016.12.004

Brettel, M., Friederichsen, N., Keller, M., \& Rosenberg. M. (2014). How Virtualization, Decentralization and Network Building Change the Manufacturing Landscape: An Industry 4.0 Perspective. World Academy of Science, Engineering and Technology International Journal of Information and Communication Engineering, 8(1), 37-44.

Brondoni, S.M. (2000-2001). Brand Policy and Brand Equity. Symphonya. Emerging Issues in Management (symphonya.unimib.it), (1), 5-25.

http://dx.doi.org/10.4468/2001.1.02brondoni

Brondoni, S. M. (2002). Overture de "Market-Space Management". Symphonya. Emerging Issues in Management (symphonya.unimib.it), (1), 1-6. http://dx.doi.org/10.4468/2002.1.01ouverture

Brondoni, S. M., \& Lambin, J. J. (2001). Overture de "Brand Equity". Symphonya, Emerging Issues in Management (symphonya.unimib.it), (1), 1-4.

http://dx.doi.org/10.4468/2001.1.01ouverture

Brondoni, S.M. (ed). (2018). Competitive Business Management. A global Perspective. Routledge- Giappichelli Studies in Business and Management.

Demirkan, H., \& Spohrer, J. (2014). Developing a Framework to Improve Virtual Shopping in Digital Malls with Intelligent Self-Service Systems. Journal of Retailing and Consumer Services, 21(5): 860-868.

https://doi.org/10.1016/j.jretconser.2014.02.012

de Reuver, M., Sørensen, C., Basole, R.C. (2017). The Digital Platform: A Research Agenda. Journal of Information Technology, 1-12. https://doi.org/10.1057/s41265-016-0033-3

Diana, L. (2016, May 20). InVRsion Presenta ShelfZone, il Supermercato del Futuro è Già Realtà. HDBlog.it. Retrieved from https://www.hdblog.it/2016/05/20/InVRsion-presenta-ShelfZonesupermercato-futuro/

EcommerceEurope (2015). Europe B2C Ecommerce Report 2015 (Light Version). Retrieved from http://www.ecommerce-europe.eu/app/uploads/2016/08/european-b2c-e-commerce-report-2015light-20150615.pdf-1.pdf

Grewal, D., Motyka, S., \& Levy, M. (2018). The Evolution and Future of Retailing and Retailing Education. Journal of Marketing Education, 40(1), 85-93. https://doi.org/10.1177/0273475318755838

Gummesson, E. (2008a). Total Relationship Marketing. London, United Kingdom: Routledge. https://doi.org/10.4324/9780080880112

Gummesson, E. (2008b). Extending the New Dominant Logic: From Customer Centricity to Balanced Centricity. The Journal of the Academy of Marketing Science, 36(1), 15-17.

https://doi.org/10.1007/s11747-007-0065-X

Gummesson, E., \& Polese, F. (2009). B2B Is Not an Island!. Journal of Business \& Industrial Marketing, 24(5/6), 337-350.

https://doi.org/10.1108/08858620910966228

Edited by: University of Milano - Bicocca ISSN: $1593-0319$ 
Håkansson, H, \& Snehota, I. J. (2000). The IMP Perspective: Assets and Liabilities of Business Relationships. In: J. N. Sheth \& A. Parvatiyar (Eds.), Handbook of relationship marketing, 69-93, Thousand Oaks, California: Sage. http://dx.doi.org/10.4135/9781452231310.n3

Harrison, N., Faigen, G., \& Brewer, D. (2018, February 08). Why Amazon's Grocery Store May Not Be the Future of Retail. Harvard Business Review. Retrieved from https://hbr.org/2018/02/whyamazons-grocery-store-may-not-be-the-future-of-retail

Hofmann, E., \& Rüsch, M. (2017). Industry 4.0 and the Current Status as Well as Future Prospects on Logistics. Computers in Industry, (89), 23-34.

https://doi.org/10.1016/j.compind.2017.04.002

Indri, M., Grau, A., \& Ruderman, M. (2017). Guest Editorial Special Section on Recent Trends and Developments in Industry 4.0 Motivated Robotic Solutions, IEEE Transactions on Industrial Informatics, 14(4), 1677-1680.

https://doi.org/10.1109/TII.2018.2809000

Jin, S.-A A., \& Bolecruch, J. (2009). Virtual Commerce (V-Commerce) in Second Life: The Roles of Physical Presence and Brand-Self Connection. Journal of Virtual Worlds Research. Virtual Economies, Virtual Goods and Service Delivery in Virtual Worlds, 2(4), 3-12.

https://doi.org/10.4101/jvwr.v2i4.867

Kagermann, H., Wahlster, W., \& Helbig, J. (2013). Recommendations for Implementing the Strategic Initiative INDUSTRIE 4.0. Final Report of the Industrie 4.0 Working Group. Retrieved from https://archive.org/details/FinalReportRecommendationOnStrategicInitiativeIndustrie4.0

Khalaf, R. E. H., Agard, B., \& Penz, B. (2011). Simultaneous Design of a Product Family and Its Related Supply Chain Using a Tabu Search Algorithm. International Journal of Production Research, 49(19), 5637-5656.

https://doi.org/10.1080/00207543.2010.519737

Kim, T. (2017, June 20). McDonald's Hits All-Time High as Wall Street Cheers Replacement of Cashiers With Kiosks. CNBC. Retrieved from https://www.cnbc.com/2017/06/20/mcdonalds-hitsall-time-high-as-wall-street-cheers-replacement-of-cashiers-with-kiosks.html

Kumar, V., Anand, A., \& Song, H. (2017). Future of Retailer Profitability: An Organizing Framework. Journal of Retailing, 93(1), 96-119. https://doi.org/10.1016/j.jretai.2016.11.003

Lee, Y. (2018, June 18). Google to Invest \$550 Million in Alibaba Rival JD.com. Usa Today Network's European Union Experience. Retrieved from https://eu.usatoday.com/story/money/2018/06/18/google-invest-550-million-alibaba-rival$\mathrm{jd} / 709287002 /$

Lee. J., Bagher, B., \& Kao, H.-A. (2015). A Cyber-Physical Systems Architecture for Industry 4.0Based Manufacturing Systems. Manufacturing Letters, 3, 18-23. https://doi.org/10.1016/j.mfglet.2014.12.001

Lee, J., Kao, H.-A., \& Yang, S. (2014). Service Innovation and Smart Analytics for Industry 4.0 and Big Data Environment. Procedia CIRP, 16, 3-8. https://doi.org/10.1016/j.procir.2014.02.001

Levy, M., Weitz, B. A., \& Grewal, D. (2018). Retailing Management (10th ed.). Burr Ridge, Illinois: McGraw-Hill/Irwin.

Liebowits, S. (2002). Rethinking the Networked Economy: The True Forces Driving the Digital Marketplace. AMACOM.

Lu, Y. (2017). Industry 4.0: A Survey on Technologies, Applications and Open Research Issues. Journal of Industrial Information Integration, 6, 1-10. https://doi.org/10.1016/j.jii.2017.04.005

Lusch, R. F., \& Vargo, S. L. (2014). The Service-Dominant Logic of Marketing: Dialog, Debate, and Directions. London, United Kingdom: Routledge.

Martinez, M., Di Nauta, P., \& Sarno, D. (2018). Real and Apparent Changes of Organizational Processes in the Era of Big Data Analytics. Studi Organizzativi, XIX(2), 91-107. https://doi.org/10.3280/SO2017-002005

Martinez, V., Bastl, M., Kingston, J., \& Evans, S. (2010). Challenges in Transforming Manufacturing Organisations into Product-Service Providers. Journal of Manufacturing Technology Management, 21(4), 449-469.

https://doi.org/10.1108/17410381011046571 
McGrath, M. (2016, June 16). Why 'Grocerants' Are The Future of Food Shopping. Forbes. Retrieved from

https://www.forbes.com/sites/maggiemcgrath/2016/06/16/why-grocerants-are-the-future-of-foodshopping/\#13eace341871

McKone, D., Haslehurst, R., \& Steingoltz, M. (2016, September 09). Virtual and Augmented Reality Will Reshape Retail. Harvard Business Review. Retrieved from

https://hbr.org/2016/09/virtual-and-augmented-reality-will-reshape-retail

MIT Technology Review Insights (2004, August 27). Revolution in Progress: The Networked Economy. Retrieved from

https://www.technologyreview.com/s/530241/revolution-in-progress-the-networked-economy/

National Institute of Standards and Technology (2013, January). Workshop Report on Foundations for Innovation in Cyber-Physical Systems. Retrieved from

http://www.nist.gov/el/upload/CPS-WorkshopReport-1-30-13-Final.pdf/

Nielsen (2017, August 06). Virtual Reality Has Real Appeal Among U.S. Gamers. Insigns. Retrieved from

http://www.nielsen.com/us/en/insights/news/2017/virtual-reality-has-real-appeal-among-usgamers.html

Normann, R. (2001). Reframing business: When the map changes the landscape. Chichester, United Kingdom: Wiley.

Nowiński, W., \& Kozma, M. (2017). How Can Blockchain Technology Disrupt the Existing Business Models? Entrepreneurial Business and Economics Review, 5, 173-188.

https://EconPapers.repec.org/RePEc:krk:eberjl:v:5:y:2017:i:3:p:173-188

Oesterreich, T. D., \& Teuteberg, F. (2016). Understanding the Implications of Digitisation and Automation in the Context of Industry 4.0: A Triangulation Approach and Elements of a Research Agenda for the Construction Industry. Computers in Industry, 83, 121-139.

https://doi.org/10.1016/j.compind.2016.09.006

Polese, F., Pels, J., Tronvoll, B., Bruni, R., \& Carrubbo, L. (2017). A4A Relationships. Journal of Service Theory and Practice, 27(5), 1040-1056. https://doi.org/10.1108/JSTP-05-2017-0085

Polese, F., Sarno, D., Troisi, O., \& Grimaldi, M. (2018). From B2B to A4A: An Integrated Model for Viable Value Co-Creation. Mercati e Competitività, 3, 135-161. https://doi.org/10.3280/MC2018-003008

Rennung, F., Luminosu, C. T., \& Draghici, A. (2016). Service Provision in the Framework of Industry 4.0. Procedia - Social and Behavioral Sciences, 221, 372-377. https://doi.org/10.1016/j.sbspro.2016.05.127

Riboldazzi, S. (2015). Global Markets and Development Policies in Large-Scale Retailers. Symphonya. Emerging Issues in Management (symphonya.unimib.it), (5), 8-28.

http://dx.doi.org/10.4468/2015.5.02riboldazzi

Rifkin, J. (2000). The Age of Access. Penguin Putnam.

Rüttimann, B. G., \& Stöckli, M.T. (2016). Lean and Industry 4.0 - Twins, Partners, or Contenders? A Due Clarification Regarding the Supposed Clash of Two Production Systems. Journal of Service Science and Management, 9, 485-500. http://doi.org/10.4236/jssm.2016.96051

Sebastiani, R., Montagnini, F., \& Dalli, D. (2013). Ethical Consumption and New Business Models in the Food Industry. Evidence from the Eataly Case. Journal of Business Ethics, 114, 473-488. https://doi.org/10.1007/s10551-012-1343-1

Shapiro, C., \& Varian, H. R. (1999). Information Rules. A Strategic Guide to Network Economy. Boston, Massachusetts: Harvard Business School Press.

Stanton, J. L. (2018). A Brief History of Food Retail. British Food Journal, 120(1), 172-180. https://doi.org/10.1108/BFJ-01-2017-0033

Tassinari, V. (2015). Large-Scale Retailers and Strategies in Retailer-Supplier Relationships. Symphonya. Emerging Issues in Management (symphonya.unimib.it), (5), 55-61. http://dx.doi.org/10.4468/2015.5.08tassinari

Tilley, R. P. R., \& Hicks, R. (1970). Economies of Scale in Supermarkets. The Journal of Industrial Economics, 19(1), 1-5. https://doi.org/10.2307/2097532

Vargo, S. L., \& Lusch, R. F. (2008) Service-Dominant Logic: Continuing the Evolution. Journal of the Academy of Marketing Science, 36(1), 1-10. https://doi.org/10.1007/s11747-007-0069-6 
Vargo, S. L., \& Lusch, R. F. (2016). Institutions and Axioms: An Extension and Update of ServiceDominant Logic. Journal of the Academy of Marketing Science, 44(1), 5-23. https://doi.org/10.1007/s11747-015-0456-3

Vargo, S. L, Wieland H., \& Akaka, M. A. (2015). Innovation Through Institutionalization: A Service Ecosystem Perspective. Industrial Marketing Management, 44, 63-72.

https://doi.org/10.1016/j.indmarman.2014.10.008

Voigt, K-I., \& Kiel, D. (2015). Innovative Geschäftsmodelle Durch Industrie 4.0 - Eine Branchenübergreifende Analyse aus Strategischer Perspektive. Retrieved from files.messe.de/abstracts/62559 1304_1230_KielVoigt_FAU_Unversitaetpdf.pdf

Weyer, S., Schmitt, M., Ohmer, M., \& Gorecky, D. (2015). Towards Industry 4.0 - Standardization as the Crucial Challenge for Highly Modular, Multi-Vendor Production Systems. IFACPapersOnLine, 48-3, 579-584.

https://doi.org/10.1016/j.ifacol.2015.06.143

Wilkinson, I. (2001). A History of Network and Channels Thinking in Marketing in the 20th Century. Marketing in the 20th Century. Australasian Marketing Journal, 9(2), 23-52.

https://doi.org/10.1016/S1441-3582(01)70174-7

Wilkinson, I. (2008), Business Relating Business: Managing Organisational Relation and Networks. Cheltenham, United Kingdom: Edward Elgar.

Yousept, I., \& Li, F. (2004). Online Supermarkets: Emerging Strategies and Business Models in the UK. Proceedings of 17 th Bled E-Commerce Conference (pp.1-22). Bled, Slovenia: eGlobal. 